\title{
Mechanisms of Subsurface Drip Irrigation-Mediated Suppression of Lettuce Drop Caused by Sclerotinia minor
}

\author{
A. A. Bell, L. Liu, B. Reidy, R. M. Davis, and K. V. Subbarao
}

First, second, third, and fifth authors: Department of Plant Pathology, University of California, Davis, c/o U.S. Agricultural Research Station, 1636 E. Alisal Street, Salinas, CA 93905; and fourth author: Department of Plant Pathology, University of California, Davis 95616. Accepted for publication 2 December 1997.

\begin{abstract}
Bell, A. A., Liu, L., Reidy, B., Davis, R. M., and Subbarao, K. V. 1998. Mechanisms of subsurface drip irrigation-mediated suppression of lettuce drop caused by Sclerotinia minor. Phytopathology 88:252-259.

Subsurface drip irrigation and associated mandatory minimum tillage practices significantly reduced the incidence of lettuce drop (Sclerotinia minor) and the severity of corky root on lettuce compared with furrow irrigation and conventional tillage. Three possible mechanisms for the drip irrigation-mediated disease suppression were examined in this study: qualitative and quantitative differences in the soil microflora under furrow and subsurface drip irrigation; their antagonism and potential biocontrol effects on S. minor; and the physical distribution of soil moisture and temperature relative to the two irrigation methods. To determine if the suppressive effects under subsurface drip irrigation were related to changes in soil microflora, soils were assayed for actinomycetes, bacteria, and fungi during the spring and fall seasons. The effects of the irrigation methods on microbial populations were nearly identical during both seasons. In the spring season, the total number of fungal colonies re-

methods during either season. No interaction between sampling time and irrigation methods was observed for any of the microbial populations during both seasons. Thus, the significant effect of sampling time observed for actinomycete and bacterial populations during the spring was most likely not caused by the irrigation treatments. There were also no qualitative differences in the three groups of soil microflora between the irrigation treatments. Even though some fungal, actinomycete, and bacterial isolates suppressed mycelial growth of $S$. minor in in vitro assays, the isolates came from both subsurface drip- and furrow-irrigated soils. In in planta assays, selected isolates failed to reduce the incidence of drop in lettuce plants. The soil moisture under subsurface drip irrigation was significantly lower at all depths and distances from the bed center after an irrigation event than under furrow irrigation. The soil temperature, in contrast, was significantly higher at both 5 and $15 \mathrm{~cm}$ depths under drip irrigation than under furrow irrigation. The suppression of lettuce drop under subsurface drip irrigation compared with furrow irrigation is attributed to differential moisture and temperature effects rather than to changes in the soil microflora or their inhibitory effects on S. minor.
\end{abstract} covered on potato dextrose agar amended with rose Bengal generally was greater in soils under drip irrigation than under furrow irrigation, but no such differences were observed during the fall. Numbers of actinomycetes and bacteria were not significantly different between irrigation
Additional keywords: biological control, cultural control, soil suppressiveness.
Diseases caused by soilborne pathogens impose a severe biotic constraint on lettuce (Lactuca sativa L.) production throughout California. Lettuce drop caused by Sclerotinia minor Jagger and corky root caused by Rhizomonas suberifaciens cause significant economic losses in coastal valleys of California. Symptoms of lettuce drop include a soft watery rot of the crown and root of both head and leaf lettuce $(1,16)$. S. minor infects roots and crowns by eruptive mycelial germination of soilborne sclerotia $(16,17)$. Corky root symptoms consist initially of banded yellow areas on the taproot that become progressively corky and dark greenish-brown. Severely infected plants remain undersized and often are too small to be harvested (22).

Lettuce production in coastal California occurs under different types of irrigation. Traditionally, furrow irrigation was used because of the ease with which it can be operated. However, with furrow irrigation, water use is high and inefficient and salt accumulation on planting beds is a major problem. In the late 1960s, growers largely adopted sprinkler irrigation for optimal seedling emergence and plant stand establishment (23). Sprinklers offered many advantages for lettuce production such as decreased salt accu-

Corresponding author: K. V. Subbarao; E-mail address: kvsubbarao@ucdavis.edu

Publication no. P-1998-0121-01R

This article is in the public domain and not copyrightable. It may be freely reprinted with customary crediting of the source. The American Phytopathological Society, 1998. mulation near seed rows, rapid and uniform application of water, higher and more uniform seedling emergence, more efficient use of water, and higher yields (23). Under both furrow and sprinkler irrigation, a large volume of soil becomes saturated, which can facilitate higher lettuce drop incidence and corky root severity $(20,21)$. With the potential shortage of available water for vegetable production, the need for preventing contamination of groundwater resources by fertilizers and pesticides and for conservation of water by more efficient irrigation methods is an urgent priority (14).

Subsurface drip irrigation holds promise for conservation of water. It requires nearly half the water needed by furrow and sprinkler systems (6) and, since fertilizers can be applied directly to the root zone, fertilizer efficiency is increased, while $\mathrm{NO}_{3}{ }^{-}$leaching is decreased. Installation of subsurface drip irrigation is initially expensive, but once the system is in place, operating costs are low.

Irrigation can have a major impact on soilborne pathogens because of its influence on soil moisture (18). A comparative study of furrow and subsurface drip irrigation on diseases and yield of lettuce revealed a significant reduction in the incidence of lettuce drop and severity of corky root under subsurface drip irrigation (21). In addition, yield of lettuce was significantly increased under subsurface drip irrigation $(20,21)$. Significantly more $S$. minor sclerotia were added to the soil after each lettuce crop under furrow irrigation as compared with subsurface drip irrigation. Populations of sclerotia increased about fivefold after 3 years of conventional tillage under furrow irrigation (19). Spatial patterns of sclerotia were less aggregated in these plots than in drip-irrigated 
plots (19). With subsurface drip irrigation, the distribution patterns and the numbers of sclerotia in plots were changed little by minimum tillage practices (19).

In this study, the potential mechanisms of disease suppression by drip irrigation were elucidated. Experiments were conducted to determine if irrigation methods caused qualitative, quantitative, or both changes in the soil microflora (fungi, bacteria, and actinomycetes); if microflora exhibited antagonism towards $S$. minor; and if the subsurface drip-mediated disease suppression was a function of the physical distribution of moisture and temperature. Preliminary results have been published previously (5).

\section{MATERIALS AND METHODS}

Field sites and plot treatments. The experiment was initiated in spring 1993 at the Hartnell East Campus in Salinas, CA, to determine the effects of irrigation and tillage practices on lettuce drop incidence, yield losses, and sclerotial dynamics over time (19-21). The soil was an Antioch fine sandy loam (23\% clay, $32 \%$ silt, $45 \%$ sand, and $2.2 \%$ organic matter) with a $\mathrm{pH}$ of 7.1 .

Treatments included subsurface drip irrigation plus minimum tillage and furrow irrigation plus conventional tillage. The irrigation treatments in the experiment were arranged in a randomized complete block design with three replications. The plots were $25 \mathrm{~m}$ in length and six beds wide, with $1 \mathrm{~m}$ between beds. To prevent edge effects, the plots were separated by a border row that belonged to neither type of irrigation. In plots with subsurface drip irrigation, a single drip irrigation line $(0.5-\mathrm{mm}$ plastic drip tape; TSystems International, San Diego, CA), with emitters spaced $20 \mathrm{~cm}$ apart, was buried $25 \mathrm{~cm}$ below the soil surface in the middle of the raised beds prior to planting of the first lettuce crop. These feeder tapes were connected to a main line that, in turn, was connected to the source of the water supply. The drip tape remained in the soil for the duration of the study.

Susceptible lettuce cultivars "Salinas" and "Misty Day" were sown in the spring and fall of each year, respectively, at a seeding rate of $300 \mathrm{~g}$ per ha. Differences in the incidence of lettuce drop under the two irrigation methods were not influenced by either the season or the cultivar (21). During both seasons each year, plots were fertilized with ammonium nitrate at the rate of $160 \mathrm{~kg}$ of $\mathrm{N}$ per ha in banded, split applications. Soon after planting, all plots were irrigated with sprinklers to facilitate uniform emergence of lettuce seedlings. Sprinkler irrigation was continued until thinning. Three weeks after emergence, the lettuce seedlings were thinned to a spacing of $30 \mathrm{~cm}$. Preliminary assays of soil samples collected from the experimental plots indicated a very low density of $S$. minor sclerotia. All lettuce plants in the experiment were inoculated with a monosclerotial isolate of $S$. minor in the spring of 1993. One week after thinning, one $S$. minor-infested rye kernel was placed $5 \mathrm{~mm}$ from the crown of each plant (21). Irrigation treatments began immediately after thinning each season with subsurface drip plots watered twice weekly and furrow plots watered once weekly based on the evapotranspiration rates for lettuce in this area.

To determine whether disease suppression mediated by drip irrigation was related to the physical distribution of soil moisture and temperature, both parameters were recorded in the furrowand drip-irrigated plots during each season. Gypsum blocks (Soil Moisture Equipment Co., Santa Barbara, CA) were buried 2, 4, and $6 \mathrm{~cm}$ from either side of the bed center in each plot. One set of blocks was buried $5 \mathrm{~cm}$ deep and another set was buried $15 \mathrm{~cm}$ deep. The electrical resistance of the gypsum blocks was recorded daily for 2 weeks immediately after the irrigation treatments were begun. The electrical resistance readings were converted into megapascals $(\mathrm{MPa})$ based on the charts provided by the manufacturer. Mean soil moisture and the corresponding standard errors of the mean for each distance and depth in each treatment were computed.

Soil temperatures were recorded hourly during the same period using soil temperature probes connected to a $21 \mathrm{X}$ data-logger
(Campbell Scientific Inc., Logan, UT) at 5 and $15 \mathrm{~cm}$ depths. Soil temperature readings for each $24-\mathrm{h}$ period were averaged to give the mean daily temperature for each day.

After crop harvest each season, the minimum tillage under subsurface drip irrigation and conventional tillage in the furrow-irrigated plots were introduced. Minimum tillage involved maintaining the integrity of semipermanent beds, which were reformed after shallow disking and chisel plowing. The conventional tillage involved disking, soil ripping to $30 \mathrm{~cm}$, chiseling, and reforming planting beds. Plot preparation procedures recommended for the subsequent crop in the two irrigation treatments were followed.

Soil sampling and processing. Soil samples for quantitative and qualitative determination of the populations of microflora in irrigation treatments were collected from each plot at different intervals. Samples were collected to a depth of $15 \mathrm{~cm}$ at three random locations from the middle four beds of each plot and bulked to provide about 500 to $700 \mathrm{~g}$ of soil. In the spring, soil samples were collected before lettuce planting, at weekly intervals after thinning until harvest, and at 5-day intervals after the incorporation of lettuce residues into the soil. In the fall, soil samples were collected before lettuce planting and daily after thinning for 2 weeks, and subsequently, at weekly intervals until harvest. Soil samples were not collected after the incorporation of lettuce residues in the fall, because no significant effects were recorded in spring. Soil samples were immediately transported to the laboratory, and soil moisture was determined gravimetrically. Fungal and bacterial populations were determined within $24 \mathrm{~h}$. Populations of actinomycetes were determined after air-drying the soil for 10 days at room temperature.

To assess soil microflora, $10 \mathrm{~g}$ of each soil sample was suspended in $90 \mathrm{ml}$ of sterile water, vigorously shaken for $10 \mathrm{~min}$, and serially diluted. For isolation of fungi, dilutions of $10^{-2}$ to $10^{-3}$ were plated on potato dextrose agar (PDA) (Difco Laboratories, Detroit) amended with $50 \mu \mathrm{g}$ of rose Bengal per $\mathrm{ml}$ and $100 \mu \mathrm{g}$ of rifampicin per ml. Plates were incubated at $25^{\circ} \mathrm{C}$ for 5 to 7 days before the numbers and types of fungal colonies were recorded. Dilutions of $10^{-5}$ to $10^{-6}$ were plated on $0.5 \%$ tryptic soy agar (TSA [tryptic soy broth $\{$ TSB $\}, 5$ g/liter, plus Bacto agar, $15 \mathrm{~g} /$ liter]) (BBL Microbiology Systems, Becton Dickinson, Cockeysville, $\mathrm{MD}$ ) and incubated at $28^{\circ} \mathrm{C}$ for $48 \mathrm{~h}$ before recording the numbers of bacterial colonies. For actinomycetes, dilutions of $10^{-2}$ to $10^{-3}$ were plated on actinomycete isolation agar (Difco Laboratories) and incubated at $25^{\circ} \mathrm{C}$ for 5 to 7 days before recording the numbers of colonies. Fungal and actinomycete colonies were isolated in pure culture and stored on PDA slants at $4{ }^{\circ} \mathrm{C}$, and bacteria were stored in TSB (Difco Laboratories) amended with 15\% glycerol at $-70^{\circ} \mathrm{C}$. From each treatment at three sampling times (prior to the beginning of the treatment, during mid-season, and after lettuce incorporation), five to eight randomly chosen colonies each of actinomycetes, bacteria, and fungi were stored for identification. Those selected represented approximately 50\% of the total population in the plates.

Identification of soil microflora. Bacteria and actinomycetes were identified by analysis of cellular fatty acids using the Microbial Identification System (MIS, version 2.11) developed by Microbial ID, Inc. (MIDI, Newark, DE). A total of 54 actinomycetes and 72 bacterial isolates that were viable 6 months after collection were used in this study. Frozen bacterial isolates were inoculated onto nutrient agar to check for purity, and then inoculated onto TSA plates divided into four quadrants and incubated at $28^{\circ} \mathrm{C}$ for $24 \pm 1 \mathrm{~h}$. A 4-mm-diameter loopful ( $\cong 40 \mathrm{mg}$ fresh weight) of cells were harvested from quadrants 2 and 3 and placed in the bottom of a glass screw-top tube. Actinomycete isolates previously stored on PDA slants were inoculated into $20 \mathrm{ml}$ of TSB (BBL Microbiology Systems, Becton Dickinson) in 150-ml Erlenmeyer flasks and shaken at $150 \mathrm{rpm}$ for at least $48 \mathrm{~h}$ at $28^{\circ} \mathrm{C}$. Some isolates of actinomycetes required longer incubation to obtain adequate growth for extraction. Cells were harvested by centrifugation (Sorvall 
RC5-B refrigerated centrifuge; Sorvall Instruments, Newtown, CT) at $2,445 \times g$ for $10 \mathrm{~min}$ at $4^{\circ} \mathrm{C}$, and approximately $200 \mathrm{mg}$ was placed in the bottom of a glass screw-top tube. Fatty acids from both bacteria and actinomycete isolates were extracted according to the method described in the Sherlock MIDI manual (version 6; Microbial ID, Inc.). In this process, cellular fatty acids were saponified, methylated to form fatty acid methyl esters, extracted from the aqueous phase into an organic phase, washed, and stored in the freezer until analyzed. The fatty acid methyl esters were separated using a Hewlett-Packard 5890A gas chromatograph (HewlettPackard Co., Cupertino, CA). Bacteria were identified using the MIS 'aerobe library' package (version 3.9; Microbial ID, Inc.) and actinomycetes using the MIS 'yeast library' package (Microbial ID, Inc.). Isolates with a similarity index of $>0.5$ were considered good matches to the library comparisons and so identified (version 3.8; Microbial ID, Inc.). A total of 67 fungal isolates were identified to the genus level based on morphological characteristics.

Statistical analysis. Population sizes of microflora were transformed to $\log \mathrm{CFU} / \mathrm{g}$ of dry soil to normalize data before analysis. Repeated measures analysis of variance (ANOVA) was used (General Linear Models of SAS version 6.11; SAS Institute, Cary, NC) to evaluate the effects of irrigation treatment, time of sampling,

TABLE 1 . Identity and number of actinomycetes, bacteria, and fungi isolated from soil under different irrigation methods

\begin{tabular}{|c|c|c|}
\hline \multirow[b]{2}{*}{ Microorganism } & \multicolumn{2}{|c|}{$\begin{array}{l}\text { Number of genera isolated } \\
\text { from each treatment }{ }^{\mathrm{a}}\end{array}$} \\
\hline & DS & $\mathrm{F}$ \\
\hline \multicolumn{3}{|l|}{ Actinomycetes } \\
\hline Streptomyces halstedii olivaceous ${ }^{\mathrm{b}}$ & 8 & 10 \\
\hline S. violaceusniger violaceusniger ${ }^{\mathrm{b}}$ & 10 & 11 \\
\hline S. lavendule ${ }^{\mathrm{b}}$ & 3 & 2 \\
\hline S. californicus $^{\mathrm{b}}$ & 4 & 6 \\
\hline \multicolumn{3}{|l|}{ Bacteria } \\
\hline Arthrobacter globiformis & 0 & 1 \\
\hline A. oxydans ${ }^{\mathrm{b}}$ & 3 & 2 \\
\hline A. pascens ${ }^{\mathrm{b}}$ & 2 & 3 \\
\hline A. viscosus & 1 & 2 \\
\hline Bacillus brevis & 1 & 0 \\
\hline B. filicolonicus & 1 & 2 \\
\hline B. laterosporus ${ }^{\mathrm{b}}$ & 7 & 5 \\
\hline B. megaterium ${ }^{\mathrm{b}}$ & 9 & 5 \\
\hline B. pumilus ${ }^{\mathrm{b}}$ & 1 & 1 \\
\hline B. psychrophilus ${ }^{\mathrm{b}}$ & 1 & 2 \\
\hline B. subtillus & 1 & 0 \\
\hline Micrococcus kristinae & 1 & 1 \\
\hline M. luteus & 1 & 1 \\
\hline M. roseus & 1 & 1 \\
\hline M. varians & 1 & 1 \\
\hline Alcaligenes piechaudii ${ }^{\mathrm{b}}$ & 1 & 1 \\
\hline Clavibacter michiganense & 0 & 1 \\
\hline Paenibacillus pabuli ${ }^{\text {b }}$ & 1 & 1 \\
\hline \multicolumn{3}{|l|}{ Fungi } \\
\hline Acremonium spp. & 0 & 2 \\
\hline Aspergillus spp. ${ }^{\mathrm{b}}$ & 8 & 1 \\
\hline Cylindrocarpon spp. & 0 & 1 \\
\hline Fusarium oxysporum $^{\mathrm{b}}$ & 4 & 2 \\
\hline F. culmorum & 1 & 1 \\
\hline Gliocladium spp. & 1 & 0 \\
\hline Mortierella spp. & 0 & 1 \\
\hline Mucor spp. & 6 & 5 \\
\hline Penicillium spp. ${ }^{\text {b }}$ & 13 & 8 \\
\hline Phoma spp. ${ }^{\mathrm{I}}$ & 0 & 1 \\
\hline Rhizopus spp. & 1 & 0 \\
\hline Sclerotinia spp. & 0 & 1 \\
\hline Trichoderma spp. ${ }^{\mathrm{b}}$ & 4 & 5 \\
\hline Ulocladium spp. & 1 & 0 \\
\hline
\end{tabular}

${ }^{\mathrm{a}} \mathrm{DS}=$ subsurface drip irrigation plus minimum tillage and $\mathrm{F}=$ furrow irrigation plus conventional tillage.

b Isolates used in the in planta assay for the biocontrol activity against of lettuce drop. and interactions on each group of microflora. Polynomial contrasts of the effects of irrigation over time were also constructed for each group of microflora for each season when time $\times$ treatment interactions were significant. Treatment means and standard errors of the mean were computed, and means were compared using a least significant difference test $(P<0.05)$.

In vitro screening for antagonism to $S$. minor. Isolates of fungi, bacteria, and actinomycetes from the lettuce field were screened to determine potential antagonism to $S$. minor. Antagonism to both germination and subsequent mycelial growth of sclerotia were determined. To obtain sclerotia, 125-ml Erlenmeyer flasks containing $45 \mathrm{~g}$ of $1-\mathrm{cm}^{3}$ potato pieces were autoclaved for $20 \mathrm{~min}$ at $121^{\circ} \mathrm{C}$. Flasks were cooled at room temperature for $24 \mathrm{~h}$ and then re-autoclaved. Flasks were then inoculated with a mycelial plug of $S$. minor isolate SM 18 grown on PDA and incubated at $24^{\circ} \mathrm{C}$ for 3 weeks. Sclerotia were washed off the potato pieces and dried for $12 \mathrm{~h}$ at $30^{\circ} \mathrm{C}$.

A total of 75 fungal isolates were evaluated for ability to inhibit germination or mycelial growth of $S$. minor. Each isolate was grown on PDA, and the growth was rated on a 0 to 3 scale $(0=$ very slow growing, 1 = slow growing, 2 = fast growing, and $3=$ very fast growing). Each assay plate contained $15 \mathrm{ml}$ of PDA to ensure uniform agar thickness and prevent its influence on the size of the inhibition zone (8). A 6-mm-diameter mycelial plug of each isolate was placed together with a single sclerotium (surface-sterilized $2 \mathrm{~min}$ in $0.5 \% \mathrm{NaOCl}) 5 \mathrm{~cm}$ apart in a 9-cm-diameter petri dish. Placement of isolates was adjusted for their intrinsic growth rates. Very fast-growing isolates (rate 3) were placed on the agar $24 \mathrm{~h}$ after the sclerotia, very slow-growing isolates (rate 0 ) were placed on the agar $24 \mathrm{~h}$ before the sclerotia, and isolates of intermediate growth (rates 1 and 2) were placed on the agar at the same time as the sclerotia. Plates were incubated at $25^{\circ} \mathrm{C}$ for either 4 days (rate 3), 5 or 6 days (rates 1 and 2), or 7 days (rate 0 ) before recording the inhibition zone using the scale $0=$ no inhibition zone, 1 = small inhibition zone or $S$. minor growing up to but not beyond the test isolate, and $2=$ large inhibition zone. The experiments were conducted two times.

The potential antagonism of bacterial isolates against $S$. minor was evaluated using the method of Adetuyi and Cartwright (3). Each 9-cm-diameter plate containing PDA was inoculated with $0.5 \mathrm{ml}$ of each culture suspension. The plates were incubated for $48 \mathrm{~h}$ at $25^{\circ} \mathrm{C}$ to ensure that the plate surfaces were uniformly covered with bacterial growth. A glass beaker was placed rim side down on each culture, and then removed and imprinted onto a fresh plate containing PDA to produce a concentric circle of bacterial growth on the surface. Plates were incubated for $24 \mathrm{~h}$ at $24^{\circ} \mathrm{C}$, and a single sclerotium (surface-sterilized for $2 \mathrm{~min}$ in $0.5 \%$ $\mathrm{NaOCl}$ ) was placed in the center of the bacterial ring. Cultures were incubated 5 more days and the degree of inhibition scored: $0=$ no inhibition zone, $1=$ small inhibition zone or $S$. minor grew up to but not beyond the test isolate, and $2=$ strong inhibition of $S$. minor indicated by a large inhibition zone. The procedure was repeated once for each isolate.

The in vitro antagonistic activity of isolated actinomycetes against $S$. minor was evaluated using a method described by O'Brien et al. (13). Each isolate was streaked across the center of a 9-cm-diameter petri dish containing PDA. After the plates were incubated for 2 days at $24^{\circ} \mathrm{C}$, a single surface-sterilized sclerotium was placed on either side of the test strain at a distance of $4 \mathrm{~cm}$. Plates were incubated for 5 days, and the degree of inhibition were recorded using the scale described above. The experiment was repeated once.

In planta screening of select isolates for biocontrol potential. To determine the correlation between the in vitro screen and efficacy of isolates to control lettuce drop in planta, four antagonistic and nonantagonistic isolates from each collection of fungi, bacteria, and actinomycetes were selected. Lettuce cultivar Salinas was sown into autoclaved riverbed sand (95\% sand, 5\% loam, and 0\% 
organic matter) in trays and transplanted 2 weeks after emergence to pots $(8$-cm-diameter) with $500 \mathrm{~g}$ of autoclaved riverbed sand amended with $30 \mathrm{~S}$. minor sclerotia.

Cultures of bacteria and actinomycetes were grown in $100 \mathrm{ml}$ of TSB in 250-ml Erlenmeyer flasks on a shaker $(100 \mathrm{rpm})$ at $28^{\circ} \mathrm{C}$ for 3 or 6 days, respectively. Cultures were then centrifuged at $2,445 \times g$ for $10 \mathrm{~min}$ and the supernatant discarded. Pellets were resuspended in $600 \mathrm{ml}$ of sterile water, and $50 \mathrm{ml}$ of the suspension was poured into 10 replicate pots for each isolate. To produce fungal inoculum, isolates were grown on PDA in petri dishes for 6 days at $24^{\circ} \mathrm{C}$. A culture suspension of each isolate was prepared by mixing six plates in $600 \mathrm{ml}$ of sterile water in a Waring blender (Waring, New Hartford, CT) for $8 \mathrm{~s}$. Each of 10 replicate pots received $50 \mathrm{ml}$ of the suspension. Noninoculated pots received $50 \mathrm{ml}$ of sterile water. Microbial agents were poured into each pot on days 1 and 13 after transplanting. Subsequently, each plant was watered once or twice daily as needed. Plants were monitored for lettuce drop development, and the number of dead plants for each isolate was recorded and expressed as a percentage of the total. From each pot, soil was sampled to a depth of $5 \mathrm{~cm} 8$ weeks after the treatments were introduced and assayed for actinomycetes, bacteria, and fungi as described above to determine if the introduced isolates survived through the experiment. The experiment was repeated once. Data for each isolate was analyzed by ANOVA procedure.

\section{RESULTS}

Identification of microflora. A majority of the species of microflora recovered were common to both irrigation treatments (Table 1). Only Aspergillus spp. were recovered in greater frequency from drip-irrigated plots. Penicillium, Aspergillus, Fusarium, Trichoderma, and Mucor spp. were the predominant fungal genera; Bacillus and Arthrobacter were the predominant bacterial genera; and Streptomyces was the main actinomycete genus recovered from both irrigation treatments (Table 1).

Population dynamics of soil microflora. ANOVA by individual dates of sampling showed few consistent differences between irrigation treatments within dates for all microbial groups during both seasons. Repeated measures ANOVA of all data within each season showed that the irrigation treatments did not affect microbial populations during both spring and fall (Tables 2 and 3), ex-

TABLE 2. Repeated measures analysis of variance of the effect of irrigation methods on populations of soil microflora in spring

\begin{tabular}{|c|c|c|c|c|c|c|c|}
\hline \multirow[b]{2}{*}{ Source } & \multicolumn{3}{|c|}{ Irrigation and block effects } & \multicolumn{4}{|c|}{ Time effects } \\
\hline & $\mathrm{df}^{\mathrm{a}}$ & $\mathrm{MS}^{\mathrm{b}}$ & $P>F^{\mathrm{c}}$ & Source $^{\mathrm{d}}$ & df & MS & $P>F$ \\
\hline \multicolumn{8}{|l|}{ Actinomycetes } \\
\hline Replicate blocks & 2 & 0.0703 & 0.2697 & DSA & 7 & 0.0008 & 0.0028 \\
\hline Irrigation & 1 & 0.0007 & 0.9046 & DSA*REP & 14 & 0.0012 & 0.1460 \\
\hline \multirow{2}{*}{ Error } & 8 & 0.0454 & & DSA*IRR & 7 & 0.1347 & 0.3973 \\
\hline & & & & Error & 56 & 0.0273 & \\
\hline \multicolumn{8}{|l|}{ Bacteria } \\
\hline Replicate blocks & 2 & 0.0032 & 0.9236 & DSA & 7 & 0.0002 & 0.0005 \\
\hline Irrigation & 1 & 0.1818 & 0.0669 & DSA*REP & 14 & 0.0031 & 0.0685 \\
\hline \multirow{2}{*}{ Error } & 8 & 0.0404 & & DSA*IRR & 7 & 0.0332 & 0.1115 \\
\hline & & & & Error & 56 & 0.0706 & \\
\hline \multicolumn{8}{|l|}{ Fungi } \\
\hline Replicate blocks & 2 & 0.0361 & 0.4817 & DSA & 7 & 0.1287 & 0.1723 \\
\hline Irrigation & 1 & 2.1106 & 0.0002 & DSA*REP & 12 & 0.0598 & 0.3078 \\
\hline \multirow[t]{2}{*}{ Error } & 8 & 0.0444 & & DSA*IRR & 7 & 0.0733 & 0.0855 \\
\hline & & & & Error & 56 & 0.0936 & \\
\hline
\end{tabular}

a Degrees of freedom.

b Mean squares.

' For DSA, DSA*REP, and DSA*IRR, Wilks' $\lambda$ and the associated probabilities are given. For others, probabilities associated with the $F$ test are presented.

${ }^{\mathrm{d}} \mathrm{DSA}=$ time of sampling, $\mathrm{REP}=$ replicate blocks, and IRR = irrigation.

TABLE 3. Repeated measures analysis of variance of the effect of irrigation methods on populations of soil microflora in fall

\begin{tabular}{|c|c|c|c|c|c|c|c|}
\hline \multirow[b]{2}{*}{ Source } & \multicolumn{3}{|c|}{ Irrigation and block effects } & \multicolumn{4}{|c|}{ Time effects } \\
\hline & $\mathrm{df}^{\mathrm{a}}$ & $\mathrm{MS}^{\mathrm{b}}$ & $P>F^{\mathrm{c}}$ & Source $^{\mathrm{d}}$ & df & MS & $P>F$ \\
\hline \multicolumn{8}{|l|}{ Actinomycetes } \\
\hline Replicate blocks & 2 & 0.0558 & 0.0642 & DSA & 15 & 0.2107 & 0.3243 \\
\hline Irrigation & 1 & 0.0456 & 0.0622 & DSA*REP & 30 & 0.0536 & 0.2759 \\
\hline \multirow[t]{2}{*}{ Error } & 8 & 0.0141 & & DSA*IRR & 15 & 0.2140 & 0.5696 \\
\hline & & & & Error & 120 & 0.0399 & \\
\hline \multicolumn{8}{|l|}{ Bacteria } \\
\hline Replicate blocks & 2 & 0.0786 & 0.5531 & DSA & 15 & 0.0064 & 0.1580 \\
\hline Irrigation & 1 & 0.0062 & 0.7236 & DSA*REP & 30 & 0.0117 & 0.2122 \\
\hline \multirow[t]{2}{*}{ Error } & 8 & 0.0465 & & DSA*IRR & 15 & 0.1190 & 0.3581 \\
\hline & & & & Error & 120 & 0.0505 & \\
\hline \multicolumn{8}{|l|}{ Fungi } \\
\hline Replicate blocks & 2 & 0.0116 & 0.7597 & DSA & 15 & 0.0391 & 0.1302 \\
\hline Irrigation & 1 & 0.0271 & 0.4384 & DSA*REP & 30 & 0.0504 & 0.5660 \\
\hline \multirow[t]{2}{*}{ Error } & 8 & 0.0407 & & DSA*IRR & 15 & 0.1967 & 0.5553 \\
\hline & & & & Error & 120 & 0.0232 & \\
\hline
\end{tabular}

a Degrees of freedom.

b Mean squares.

c For DSA, DSA*REP, and DSA*IRR, Wilks' $\lambda$ and the associated probabilities are given. For others, probabilities associated with the $F$ test are presented.

d $\mathrm{DSA}=$ time of sampling, $\mathrm{REP}=$ replicate blocks, and IRR = irrigation. 
cept for the populations of fungi during the spring season (Table 2 ). Populations of fungi in the drip-irrigated plots were significantly higher than in the furrow-irrigated plots prior to the beginning of irrigation treatments during the spring season (Fig. 1). Subsequently, populations of fungi fluctuated little in the drip-irrigated plots in contrast to wide fluctuations in furrow-irrigated plots (Fig. 1). But no such differentiation was observed between irrigations during the fall (Fig. 2). Incorporation of lettuce residue did not appear to affect numbers of fungi (Fig. 1).

The irrigation treatments did not influence the populations of actinomycetes and bacteria during both spring and fall. The effects of irrigation treatments on populations of actinomycetes and bac- teria, however, varied significantly through time during spring (Table 2), but no such differences were observed during the fall (Table 3). The interaction between time and irrigation treatment was not observed for any microbial population during both seasons (Tables 2 and 3 ).

There were no differences in the initial populations of bacteria in plots with different irrigation treatments during both spring and fall (Figs. 1 and 2). The numbers of bacteria fluctuated similarly in all plots regardless of the irrigation treatment during the spring, with final populations approximately $1 \log$ unit higher at the end of the trial compared with the numbers at pretreatment. Numbers of bacteria after the incorporation of lettuce residues (prior to
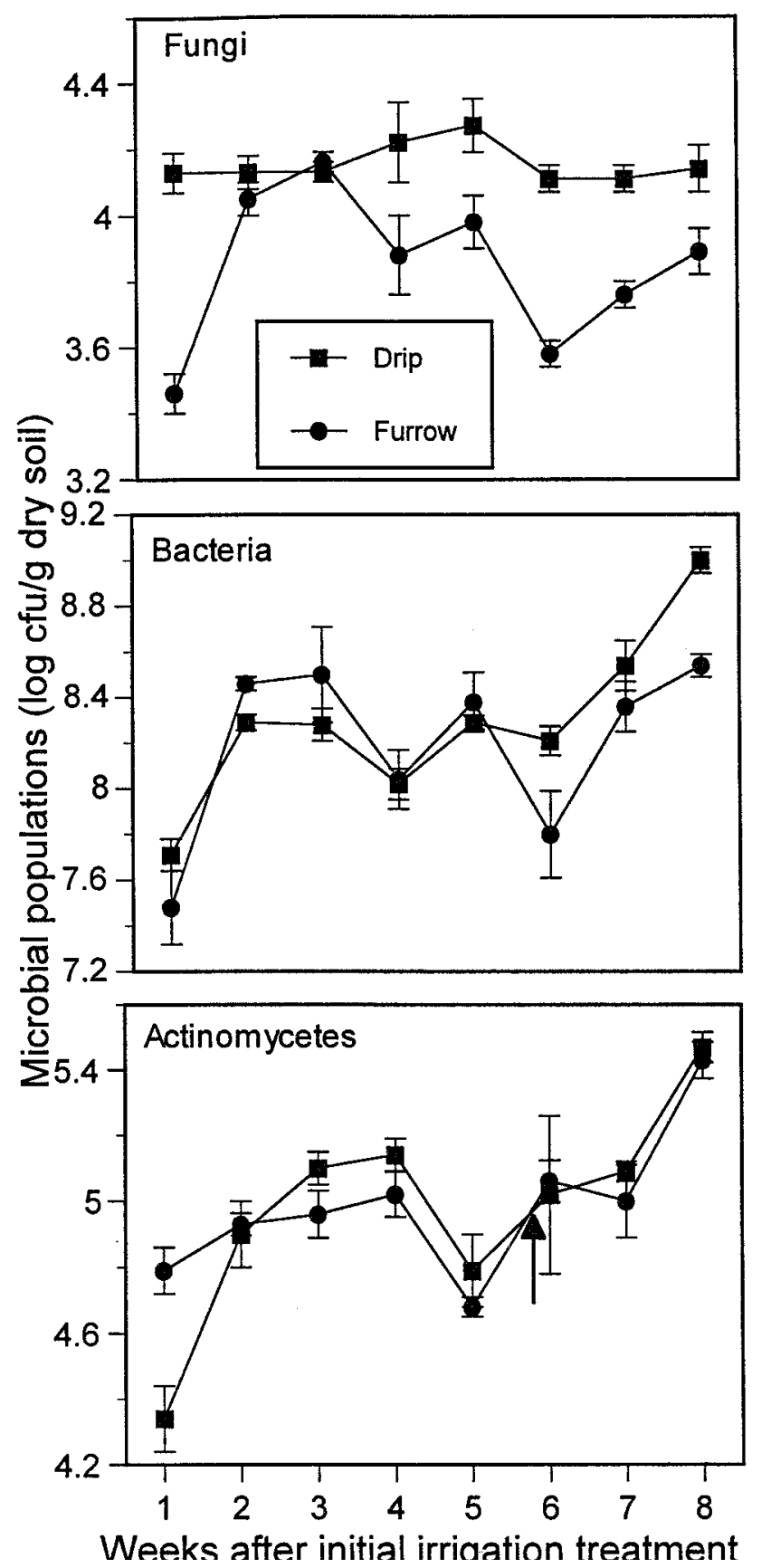

Fig. 1. Effects of irrigation on soil microbial populations in spring. The first soil sampling occurred prior to the imposition of irrigation treatments. Incorporation of lettuce residues occurred immediately prior to sampling at week 7. Samples were collected weekly 2 days after both types of irrigations occurred. The vertical bars are the standard errors of the mean. The arrow in the lowest panel indicates the time of lettuce residue incorporation.
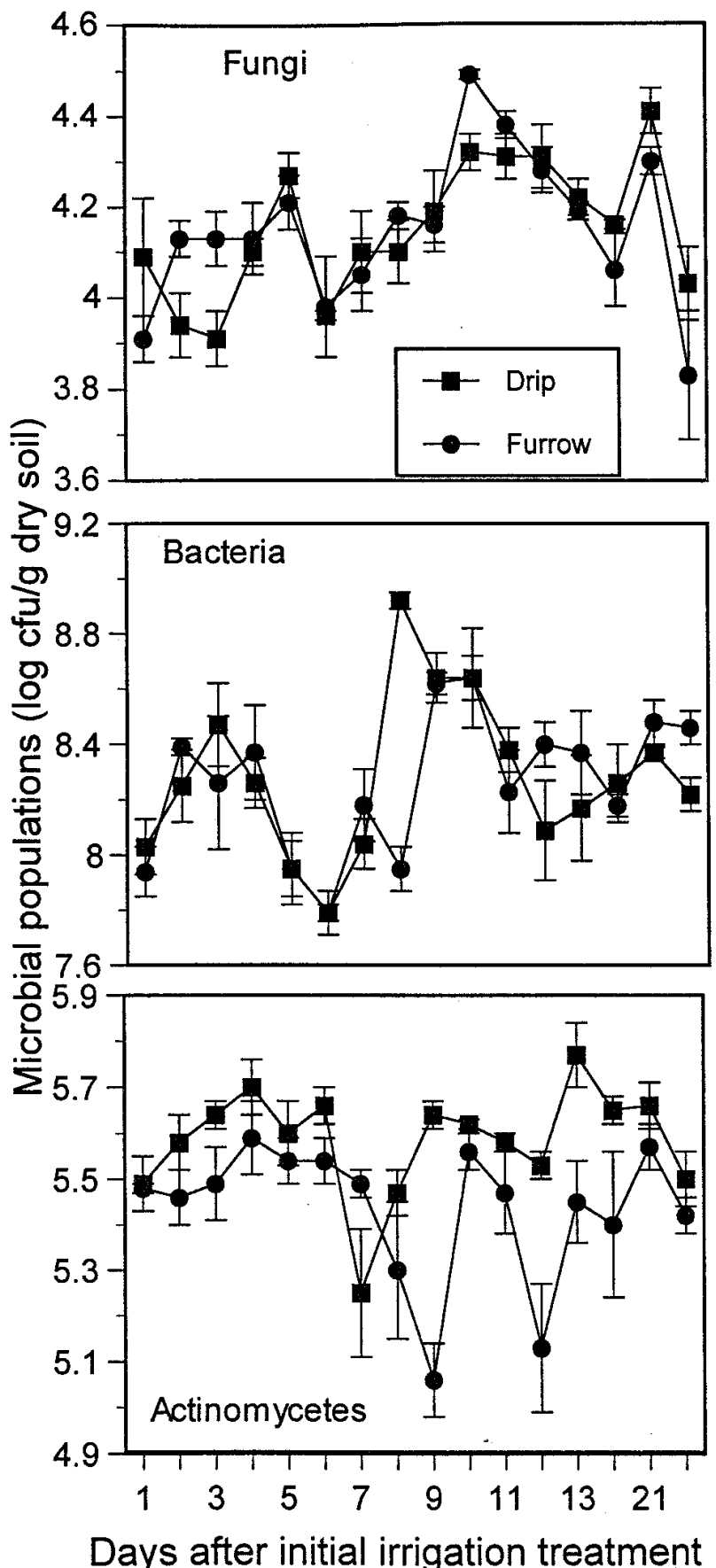

Fig. 2. Effects of irrigation on the soil microbial populations in fall. The first soil sampling occurred prior to the imposition of irrigation treatments. Soil samples were collected daily for 2 weeks after the irrigation treatments were begun. Subsequently, soil samples were collected weekly. The vertical bars are the standard errors of the mean. 
week 6 collection) increased significantly in all treatments (Fig. 1). In the fall, a bimodal pattern of increase in the numbers of bacteria was recorded through mid-season independent of the irrigation treatments, and the final populations of bacteria were nearly equivalent to the initial populations (Fig. 2).

Unlike fungi, initial populations of actinomycetes were significantly lower in the drip-irrigated plots than in the furrow-irrigated plots during the spring. Subsequently, populations of actinomycetes increased throughout the season (except in week 5) independent of treatment during the spring. Actinomycete counts also increased in all treatments following the incorporation of lettuce residues in the spring (Fig. 1). Populations of actinomycetes, however, remained relatively stable throughout the fall season in all plots, and the final populations were approximately the same as the populations detected prior to the imposition of irrigation treatments (Fig. 2).

In vitro screening for antagonism to $\boldsymbol{S}$. minor. In vitro assays revealed several isolates of fungi, actinomycetes, and bacteria strongly antagonistic to mycelial growth of $S$. minor. None of the test isolates inhibited germination of $S$. minor sclerotia. Of the isolates tested, 18 fungi, 12 bacteria, and 34 actinomycetes were strongly antagonistic to $S$. minor. There was no correlation between the origin of the test isolates from a particular irrigation treatment and the degree to which they were antagonistic to $S$. minor.
In planta screening of select isolates for biocontrol potential. Isolates evaluated in these experiments came from both subsurface drip- and furrow-irrigated plots. Results from the two experiments were consistent for all isolates. The average lettuce drop incidence on plants treated with the different isolates from the two experiments was $92 \%$ compared with $60 \%$ for the untreated control. None of the isolates, whether antagonistic or nonantagonistic to $S$. minor in vitro, reduced incidence of lettuce drop in the greenhouse. The microflora added at the beginning of the experiment were recovered from the soil after 8 weeks, suggesting that the introduced organisms survived in the soil during the experiment, although no attempt was made to identify the recovered microorganisms.

Soil moisture and temperature. Results from both spring and fall seasons with regard to soil moisture and temperature distribution were similar. There were significant differences between the furrow and subsurface drip irrigation in both the level of soil moisture and the pattern of soil moisture distribution on the bed tops (Fig. 3). In furrow-irrigated plots, soil moisture was uniformly higher at both the 5 and $15 \mathrm{~cm}$ depths compared with the dripirrigated plots (Fig. 3B and D compared with Fig. 3A and C) and was distributed uniformly across the bed tops in the furrow-irrigated plots regardless of the distance from the bed centers. Soil moisture at the $15 \mathrm{~cm}$ depth remained near field capacity for nearly
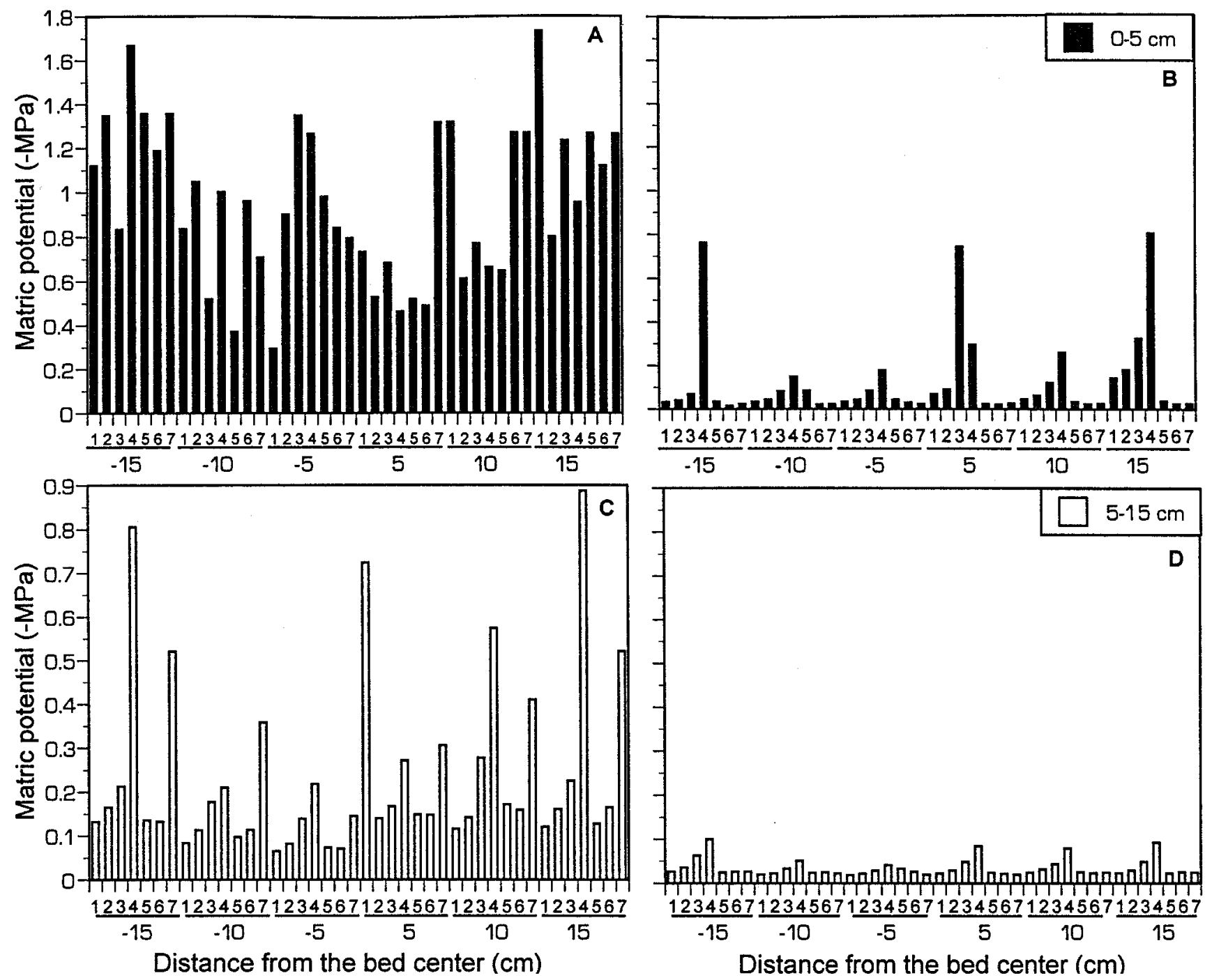

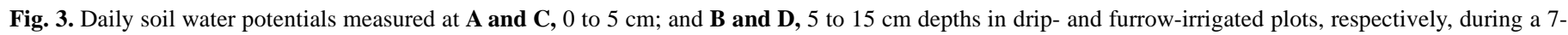

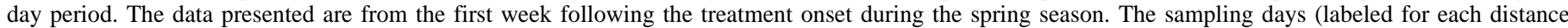
immediately below the $\mathrm{x}$ axis) are indicated for each distance on either side of the bed center. Results from all other sampling periods were similar. 
6 days following an irrigation event (day 1 at each distance is the day of irrigation in Fig. 3D). At the $5 \mathrm{~cm}$ depth, however, the soil became progressively drier and was lowest only $24 \mathrm{~h}$ prior to the following irrigation event (day 7 at each distance in Fig. 3B). At no time was soil moisture at either depth under furrow irrigation as low as in the subsurface drip-irrigated soils (Fig. 3B and D compared with Fig. 3A and C). Overall, soil moisture was lower in drip-irrigated plots than in furrow-irrigated plots at both depths and distances from the bed center at any time following an irrigation event (Fig. 3A and $\mathrm{C}$ ). At 5 and $15 \mathrm{~cm}$ depths, soil moisture decreased exponentially from the bed center. At the $5 \mathrm{~cm}$ depth, soil moisture in drip-irrigated plots was always less than $-0.3 \mathrm{MPa}$, and progressively became lower after an irrigation event. At this depth, the soil moisture was always lower in drip-irrigated plots than at any time following an irrigation event compared with the furrow-irrigated plots (Fig. 3A and B).

Fluctuations in soil temperature between the subsurface dripand furrow-irrigated plots were similar during the period of this study regardless of the season. Mean daily temperatures were higher under drip irrigation than under furrow irrigation (Fig. 4). In dripirrigated plots, mean daily temperatures at $15 \mathrm{~cm}$ were significantly higher than at $5 \mathrm{~cm}$ depth. At $15 \mathrm{~cm}$, temperatures fell less than those at $5 \mathrm{~cm}$ during the night. In furrow-irrigated plots, there was little difference between the temperatures at 5 and $15 \mathrm{~cm}$ depths (Fig. 4). There were much greater differences between maximum and minimum day and night temperatures in furrow-irrigated plots, which resulted in a lower mean daily temperature.

\section{DISCUSSION}

A significant reduction in the lettuce drop caused by $S$. minor under subsurface drip irrigation compared with furrow irrigation was previously reported (19-21). Populations of sclerotia increased slightly or not at all under subsurface drip irrigation with minimum tillage. In contrast, sclerotial populations increased nearly fivefold in plots under furrow irrigation with conventional tillage (19). In this study, three potential mechanisms of lettuce drop suppression mediated by subsurface drip irrigation were examined. The dynamics of soil microflora studied were not affected by the irrigation treatments and there were no qualitative or consistent quantitative differences in the three groups of soil microflora examined. Although isolates of some actinomycetes, bacteria, and fungi exhibited antagonism to $S$. minor in vitro, none of the tested microflora reduced the incidence of lettuce drop in vivo. Results

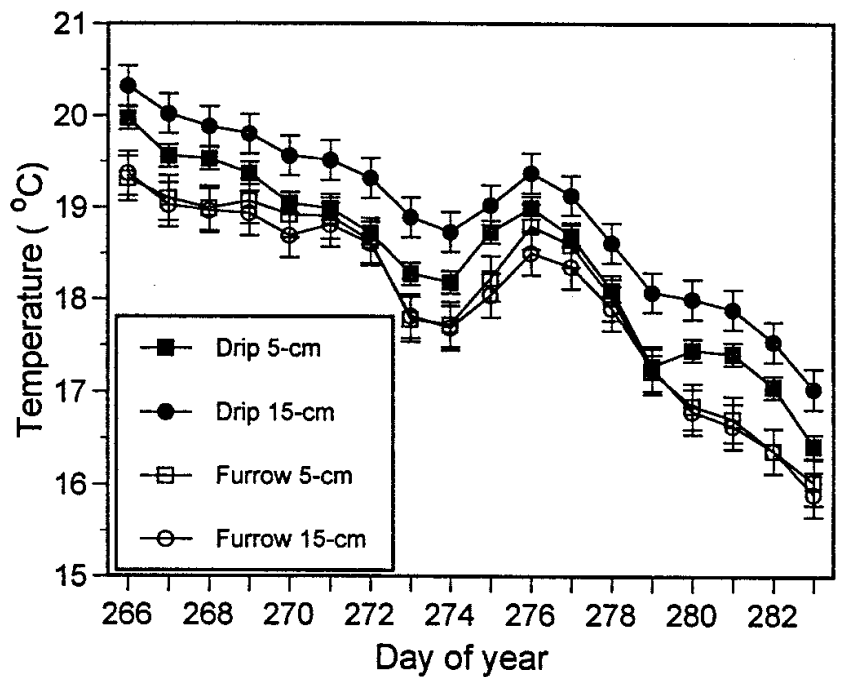

Fig. 4. Mean daily temperature in subsurface drip (DS)- and furrow (F)irrigated plots at 5 and $15 \mathrm{~cm}$ depths during a 2-week period in the fall. Results from the spring season were similar. from this study strongly suggest that the disease suppressive effects of subsurface drip irrigation compared with the conducive effects of furrow irrigation are a direct result of the differential distribution of soil moisture, and possibly temperature, under the two irrigation systems.

The numbers of the three groups of microflora examined in this study varied significantly through time within a season, but seldom between irrigation treatments. In spring, bacteria and actinomycetes increased during the growing season irrespective of irrigation treatment, possibly due to natural seasonal fluctuations. No such increases were observed during the fall season. Only populations of fungi were significantly different between the irrigation treatments during the spring season. However, there were significant quantitative differences in the initial populations of fungi between the irrigation treatments. Thus, there was no direct evidence of the changes in soil microfloral populations substantially contributing to the observed disease reduction.

While attempting to determine whether microflora or irrigation practice was responsible for the observed reduction in lettuce drop, we also were interested in identifying new potentially antagonistic microflora. Apart from the lack of qualitative differences between the species recovered from the different irrigation treatments or sampling dates, there also were no genera that were specific to any type of irrigation. Furthermore, population differences of specific members of microflora between the irrigation treatments were nonexistent. Thus, any role played by the microflora in suppressing or increasing the pathogen activity was common to both irrigation methods.

Furthermore, isolates of fungi, bacteria, and actinomycetes from the field did not suppress $S$. minor under greenhouse conditions. Although in vitro antibiosis was observed with a few isolates of each group, reduction in lettuce drop incidence by these isolates was not observed in planta. This is consistent with previous reports $(4,12,15)$ in which there was often a lack of correlation between in vitro screening systems and efficiency of biocontrol in vivo. Possible reasons for this lack of correlation between in vitro and in vivo experiments in this study include the lack of organic matter in the soil used in in vivo experiments in the greenhouse. Fravel et al. (10) demonstrated that an application of microbial agents together with an organic carrier as a substrate increased the efficacy of biocontrol. Lack of external food bases might render the added antagonists nonviable. Since root exudates may only play a minor role as sources of carbon (7), the $S$. minor sclerotia alone may have served as the food base for the antagonists. The in vitro evaluation of isolates of microflora on $S$. minor sclerotia in this study revealed antibiosis only and not hyperparasitism. Furthermore, all three groups of microflora were recovered in greater numbers at the end of the experiments in treatments to which they were added than in the control treatment, suggesting that the added microflora survived in the soil to some extent. However, lack of any evidence for biocontrol by isolates from the field indirectly supports our hypothesis that the suppression of lettuce drop under drip irrigation is due to differential moisture effects rather than to microflora.

Soil moisture and temperature, either singularly or in combination, play a vital role in the infection and colonization of plant tissues by $S$. minor $(9,11)$. Sclerotial germination and mycelial growth occurred between 6 and $30^{\circ} \mathrm{C}$ with an optimum at $18^{\circ} \mathrm{C}$, while infection of lettuce tissue by hyphae from germinating sclerotia occurred between 6 and $24^{\circ} \mathrm{C}$ with an optimum also at $18^{\circ} \mathrm{C}$ (11). Even though eruptive germination of $S$. minor sclerotia can occur between -0.03 and $1.5 \mathrm{MPa}$, the optimal soil moisture for eruptive germination is $-0.03 \mathrm{MPa}$ (11). In this study, at both 5 and $15 \mathrm{~cm}$ depths, soil temperatures were significantly higher in drip-irrigated plots than in furrow-irrigated plots. Lower soil moisture at and near the soil surface at $<35^{\circ} \mathrm{C}$ is detrimental to the survival of $S$. minor sclerotia (2). The highest soil temperatures recorded in our study were below $21^{\circ} \mathrm{C}$ in both irrigation systems, 
and thus it is unlikely that temperature was detrimental to the survival of $S$. minor sclerotia in either irrigation systems. The temperatures in furrow-irrigated plots, however, were near optimum for infection of lettuce plants by $S$. minor to a greater degree than in drip-irrigated plots. Optimum soil temperature in combination with the near-optimum soil moisture under furrow irrigation perhaps promoted lettuce drop under this system. In contrast, a combination of suboptimal soil moisture at both soil depths and supraoptimal temperature played a greater role in reducing disease incidence under subsurface drip irrigation.

\section{ACKNOWLEDGMENTS}

A. A. Bell, L. Liu, and B. Reidy contributed equally to this study. This research was supported, in part, by funding from the California Iceberg Lettuce Research Advisory Board. We thank K. Schulbach, T. Gonzales, and S. Koike for contributions to this study. We also thank A. Ford and J. Hubbard for help with the fatty acid analyses.

\section{LITERATURE CITED}

1. Abawi, G. S., Grogan, R. G., and Duniway, J. M. 1985. Effect of water potential on survival of sclerotia of Sclerotinia minor in two California soils. Phytopathology 75:217-221.

2. Adams, P. B. 1987. Effects of soil temperature, moisture, and depth on survival and activity of Sclerotinia minor, Sclerotium cepivorum, and Sporidesmium sclerotivorum. Plant Dis. 71:170-174.

3. Adetuyi, F. C., and Cartwright, D. W. 1985. Studies of the antagonistic activities of bacteria endemic to cereal seeds. II. Quantification of antimycotic activity. Ann. Appl. Biol. 107:33-43.

4. Andrews, J. H., Berbee, F. M., and Nordheim, E. V. 1983. Microbial antagonism to the imperfect stage of the apple scab pathogen, Venturia inaequalis. Phytopathology 73:228-234.

5. Bell, A. A., Liu, L., Davis, R. M., and Subbarao, K. V. 1996. Effects of irrigation practices on the soil microflora of a Sclerotinia minor infested lettuce field. (Abstr.) Phytopathology 86:S27.

6. Bernstein, L., and Francois, L. E. 1973. Comparisons of drip, furrow and sprinkler irrigation. Soil Sci. 115:73-86.

7. Cook, R. J., and Baker, K. F. 1983. The Nature and Practice of Biological Control of Plant Pathogens. The American Phytopathological Society, St. Paul, MN.

8. Dhingra, O. D., and Sinclair, J. B. 1995. Basic Plant Pathology Methods. 2nd ed. CRC Press, Boca Raton, FL.

9. Dow, R. L., Porter, D. M., and Powell, N. L. 1988. Effect of environmental factors on Sclerotinia minor and Sclerotinia blight of peanut. Phytopathology 78:672-676.

10. Fravel, D. R., Lewis, J. A., and Chittams, J. L. 1995. Alginate prill formulations of Talaromyces flavus with organic carriers for biocontrol of Verticillium dahliae. Phytopathology 85:165-168.

11. Imolehin, E. D., Grogan, R. G., and Duniway, J. M. 1980. Effect of temperature and moisture tension on growth, sclerotial production, germination, and infection by Sclerotinia minor. Phytopathology 70:1153-1157.

12. Kommendahl, T., and Windels, C. E. 1978. Evaluation of biological seed treatment for controlling root diseases of pea. Phytopathology 68:1087-1095.

13. O'Brien, J. G., Blanchette, R. A., and Sutherland, J. B. 1984. Assessment of Streptomyces spp. from elms for biological control of Dutch elm disease. Plant Dis. 68:104-106.

14. Office of Technology Assessment, U.S. Congress. 1990. Beneath the Bottom Line: Agricultural Approaches to Reduce Agrichemical Contamination of Groundwater. U.S. Government Printing Office, Washington, DC.

15. Papavizas, G. C., and Lewis, J. A. 1983. Physiological and biocontrol characteristics of stable mutants of Trichoderma viride resistant to MBC fungicides. Phytopathology 73:407-411.

16. Patterson, C. L., and Grogan, R. G. 1985. Differences in epidemiology and control of lettuce drop caused by Sclerotinia minor and S. sclerotiorum. Plant Dis. 69:766-770.

17. Patterson, C. L., and Grogan, R. G. 1988. Relationship of growth media and drying and of age of sclerotia to eruptive germination and infection by Sclerotinia minor. Plant Dis. 72:1046-1048.

18. Rotem, J., and Palti, J. 1969. Irrigation and plant diseases. Annu. Rev. Phytopathol. 9:267-288.

19. Subbarao, K. V. 1996. Epidemiology and control of lettuce drop caused by Sclerotinia minor. Annual Lettuce Research Report. Crop Year 1995. California Iceberg Lettuce Advisory Board, Salinas.

20. Subbarao, K. V., Hubbard, J. C., and Schulbach, K. F. 1994. Effects of irrigation methods on disease management in lettuce. (Abstr.) Phytopathology 84:1103-1104.

21. Subbarao, K. V., Hubbard, J. C., and Schulbach, K. F. 1997. Comparison of lettuce diseases and yield under subsurface drip and furrow irrigation. Phytopathology 87:877-883.

22. van Bruggen, A. H. C., Jochimsen, K., and Brown, P. R. 1990. Rhizomonas suberifaciens, gen. nov., sp. nov., the causal agent of corky root of lettuce. Int. J. Syst. Bacteriol. 40:175-188.

23. Whitaker, T. W., Ryder, E. J., Rubatzky, V. E., and Vail, P. V. 1974. Lettuce production in the United States. U.S. Dep. Agric. Agric. Res. Serv. Agric. Handb. 221. 